\title{
Analisis Pengaruh Service Quality, Personal Selling dan Complain Handling Melalui Satisfaction Serta Trust terhadap Customer Retention (Survei Nasabah Tabungan Bank Harda Internasional Cabang Pontianak)
}

\author{
Nico Yudhinata Lay* \\ Magister Manajemen, Universitas Tanjungpura, Indonesia \\ Erna Listiana \\ Magister Manajemen, Universitas Tanjungpura, Indonesia \\ Heriyadi \\ Magister Manajemen, Universitas Tanjungpura, Indonesia
}

\begin{abstract}
This study aims to determine the effects of service quality, personal selling and complain handling through satisfaction and trust on customer retention on the customer of Harda International Savings Bank, in Pontianak branch. The sample of this study consisted of 100 respondents of customers of Harda International Savings Bank, Pontianak. This associative study employed a survey method and a path analysis. The results of hypothesis test using test-F shows that the variables of service quality, personal selling, and complain handling have significant influence on satisfaction. Likewise the t-test results of hypothesis shows the variables of service quality, personal selling, and complain handling significantly influence satisfaction. Subsequently, satisfaction variable has significant influence on trust and customer retention. Meanwhile, trust variable has significant influence on customer retention.
\end{abstract}

Keywords: service quality, personal selling, complain handling, satisfaction, trust, customer retention

\section{PENDAHULUAN}

Dunia perbankan di Indonesia mengalami pergeseran paradigma yaitu dari melayani perusahaan/corporate banking menjadi perorangan/customer banking (Ellena \& Rahardjo, 2011). Pergeseran paradigma ini disebabkan oleh krisis ekonomi yang terjadi di Indonesia pada 1997-1998 yang mengakibatkan kinerja keuangan perusahaan dan target pasar perbankan menjadi lebih terbatas (Ellena \& Rahardjo, 2011). Perusahaan yang memiliki fokus pada customer banking menjadi lebih mampu bertahan dan memiliki keunggulan bersaing/competitive advantage. Menurut Doyle (2013),

*Email : nick_gmn@yahoo.co.id

Received : 18-05-2018, Accepted : 05-06-2018, Published : 18-08-2018

p-ISSN : 2087 - 9954, e-ISSN : 2550 - 0066. DOI:http://dx.doi.org/10.26418/jebik.v7i2.25694 
keunggulan bersaing merupakan prinsip yang baik untuk diterapkan oleh perusahaan ke aktivitasnya dibandingkan dengan para pesaingnya. Salah satu keunggulan bersaing adalah membina hubungan yang baik dengan konsumennya. Hubungan yang baik dengan konsumennya dalam jangka panjang akan mendorong pihak-pihak yang terlibat dalam hubungan menemukan cara terbaik dalam berinteraksi sehingga customer retention akan tercipta.

Customer retention akan menjadikan perusahaan semakin sulit dilupakan oleh pelanggan dan akan meningkatkan penjualan sesuai dengan tujuan pemasaran yaitu untuk meningkatkan jumlah nasabah, baik secara kuantitas maupun kualitas (Kasmir, 2014). Secara kuantitas artinya jumlah nasabah bertambah secara signifikan, sedangkan secara kualitas artinya memperoleh nasabah yang produktif yang mampu memberikan laba bagi bank. Menurut Hasan (2013) menyatakan " Customer retention merupakan sasaran dan indikator penting dalam meningkatkan pembelian berulang dan rekomendasi dari mulut ke mulut yang berdampak positif bagi perusahaan”. Untuk menjaga agar Customer retention dapat terjalin dengan baik, maka perusahaan perlu memberikan service quality kepada setiap pelanggan tanpa membedakan status sosialnya. Menurut Schmitt (2002), menyatakan hubungan pelanggan dengan perusahaan mempengaruhi customer retention karena setiap interaksi menentukan apakah pelanggan merasa puas terhadap hubungan dengan perusahaan tersebut.

Service quality adalah hal yang penting diperhatikan di jasa perbankan, karena merupakan faktor penentu keberhasilan sebuah bank (Semuel, 2012). Menurut Lovelock, Christopher \& Wright, Lauren (2007), "Service quality merupakan evaluasi jangka panjang pelanggan terhadap penyerahan jasa perusahaan". Sedangkan service merupakan suatu kegiatan yang tidak berwujud dan memberikan suatu satisfaction bagi pemakai jasa tersebut, tetapi hal ini tidak termasuk kepemilikan dan tidak dapat disimpan atau dipindahkan. Salah satu strategi yang dilakukan oleh perbankan untuk meningkatkan service quality yaitu dengan menerapkan customer retention, melalui kegiatan melayani, komunikasi dengan pelanggan dan complain handling sebagai fokus dalam membangun hubungan baik dengan konsumen (Artantie, 2014; Ndubisi, 2007; Semuel, 2012) .

Menurut Kotler \& Keller, Kevin (2012), personal selling adalah interaksi langsung dengan satu calon pembeli atau lebih guna melakukan presentasi, menjawab pertanyaan dan menerima pesanan. Personal selling memiliki pengaruh terhadap satisfaction yang akan berakibat kepada customer retention (Ngatno, 2006; Rooswitasari, 2013). Complain handling mengacu pada kemampuan pemasok untuk meminimalkan konsekuensi negatif dari komplain nyata dan potensial (Dwyer \& Tanner, 1999; Kwon \& Suh, 2006). Complain handling meliputi kemampuan pemasok untuk menghindari potensi komplain, menyelesaikan komplain sebelum menciptakan masalah dan kemampuan untuk secara terbuka mendiskusikan, solusi ketika masalah timbul (Kwon \& Suh, 2006; Ndubisi, 2005). 
Satisfaction adalah tanggapan konsumen terhadap evaluasi ketidaksesuaian yang dirasakan antara harapan yang sebelumnya atau yang diharapkan dengan kinerja produk yang dirasakan atau digunakan. Kotler \& Keller, Kevin (2012), yang dikutip dari buku Manajemen Pemasaran mengatakan satisfaction adalah perasaan senang atau kecewa seseorang yang muncul setelah membandingkan kinerja produk yang dipikirkan terhadap kinerja yang diharapkan. Trust adalah keyakinan bahwa seseorang akan menemukan yang diinginkan pada mitra pertukaran. Trust melibatkan kesediaan seseorang untuk bertingkah laku tertentu karena keyakinan bahwa mitranya akan memberikan yang ia harapkan dan harapan yang dimiliki seseorang bahwa janji-janji atau pernyataan orang lain dapat dipercaya (Barnes, 2003). Menurut Kotler, Philip \& Keller, Kevin (2013) "Trust adalah gagasan deskriptif yang dianut oleh seseorang tentang sesuatu ". Trust adalah rasa aman dalam interaksinya terhadap sesuatu yang diinginkan dan diharapkan sehingga akan memberikan hasil yang positif bagi konsumen.

Berdasarkan penjelasan di atas, penulis tertarik melakukan penelitian di Bank Harda Internasional Cabang Pontianak dengan judul penelitian " Analisis Pengaruh Service Quality, Personal Selling dan Complain Handling melalui Satisfaction serta Trust terhadap Customer Retention (Survei Nasabah Tabungan Bank Harda Internasional Cabang Pontianak)".

\section{KAJIAN LITERATUR}

Menurut Kotler \& Keller, Kevin (2012), service quality adalah keseluruhan ciri serta sifat dari suatu produk atau pelayanan yang berpengaruh pada kemampuannya untuk memuaskan kebutuhan yang dinyatakan atau tersirat. Sedangkan menurut Grinroos dalam Pujawan (1997) yang dikutip dalam Mauludin (2004), mendefinisikan service quality sebagai hasil persepsi dan perbandingan antara harapan pelanggan dengan kinerja aktual pelayanan.

Service quality adalah keseluruhan sikap pelanggan terhadap penyerahan jasa, yang terbentuk dari sejumlah pengalaman jasa. Untuk menghindari kesenjangan jasa dalam setiap penyerahan akan membantu suatu perusahaan meningkatkan nama baiknya dalam hal jasa yang bermutu. Kesenjangan jasa bukan hanya satu-satunya cara pelanggan menilai kualitas jasa. Indikator yang digunakan menurut Kotler, Philip \& Keller, Kevin (2013), yaitu keandalan, daya tangkap, kepastian, empati dan berwujud. Dalam penelitian ini, definisi service quality menunjuk kepada pendapat Kotler \& Keller, Kevin (2012), yaitu keseluruhan ciri serta sifat dari suatu produk atau pelayanan yang berpengaruh pada kemampuannya untuk memuaskan kebutuhan yang dinyatakan atau tersirat.

Personal Selling adalah suatu bentuk penyajian secara lisan dalam suatu pembicaraan dengan seseorang atau lebih dengan tujuan meningkatkan terwujudnya penjualan produk (Dharmmesta \& Irawan, 2002). Menurut Tjiptono (2005), menyatakan 
personal selling merupakan kegiatan pemasaran interaksi langsung dengan satu atau lebih pembeli guna melakukan presetansi knowledge produk, menjawab pertanyaan dan menerima pesanan dari calon pembeli. Personal Selling memiliki sifat antara lain tatap muka langsung (personal confrontantion), pemeliharaan pelanggan (cultivation) dan tanggapan (response). Dalam hal ini penjual berupaya untuk membantu atau membujuk calon pembeli untuk membeli produk yang ditawarkan. Definisi personal selling menurut Kotler \& Keller, Kevin (2012) adalah sebuah pengungkapan secara lisan dalam menghadapi seseorang atau beberapa calon pembeli dengan maksud utuk menciptakan suatu penjualan. Indikator yang digunakan menurut Wardhana \& Iba (2014), yaitu komunikasi, sikap, penguasaan produk, negosiator dan responsif.

Berdasarkan definisi diatas, dapat disimpulkan bahwa Personal Selling adalah promosi penjualan yang dilakukan dengan dua arah dan dinilai lebih efektif dalam memasarkan produk, karena tujuan akhir dalam suatu promosi adalah melakukan penjualan. Dalam penelitian ini, definisi Personal Selling menunjuk kepada pendapat Kotler \& Keller, Kevin (2012) adalah sebuah pengungkapan secara lisan dalam menghadapi seseorang atau beberapa calon pembeli dengan maksud utuk menciptakan suatu penjualan.

Complain handling merupakan sumber masukan yang positif bagi perusahaan dalam memperbaiki diri untuk memberikan pelayanan kepada para pelanggannya. Kemampuan perusahaan untuk menghindari kegagalan layanan dan komplain cenderung memiliki bantalan besar pada kepuasan pelanggan secara keseluruhan (Ndubisi, 2012). Complain handling didefinisikan sebagai kemampuan perusahaan untuk mencegah potensi sebuah komplain, menyelesaikan komplain secara nyata sebelum menjadi masalah dan mendiskusikan solusinya secara terbuka ketika ada masalah yang timbul (Ndubisi, 2007; Ningtyas \& Rachmad, 2011). Complain handling itu terjadi karena adanya ketidakpuasan pelanggan terhadap pelayanan yang diberikan oleh perusahaan, jika hal ini dibiarkan berlarut-larut akan menimbulkan dampak negatif bagi perusahaan.

Pelanggan cenderung setia pada perusahaan yang menangani complain handling dengan baik (Ndubisi, 2007). Oleh karena itu penting bahwa mekanisme resolusi komplain yang efektif tidak hanya di tempat tetapi proaktif, sehingga untuk mendahului potensi sumber komplain dan mengatasi masalah mereka sebelum menjadi nyata. Sebab, komplain dapat menciptakan dampak negatif yang kuat pada Trust (Kwon \& Suh, 2006). Indikator yang digunakan menurut Tjiptono (2008) yaitu keadilan, kewajaran dan accessible. Dalam penelitian ini, definisi complain handling menunjuk kepada pendapat Ndubisi (2007) dan Ningtyas \& Rachmad (2011) yaitu complain handling didefinisikan sebagai kemampuan perusahaan untuk mencegah potensi sebuah komplain, menyelesaikannya secara nyata sebelum menjadi masalah dan mendiskusikan solusinya secara terbuka ketika ada masalah yang timbul

Satisfaction merupakan faktor terpenting dalam berbagai kegiatan bisnis atau usaha. Satisfaction adalah tanggapan konsumen terhadap evaluasi ketidaksesuaian yang 
dirasakan antara harapan dengan kinerja produk yang dirasakan. Pelanggan akan mempunyai persepsi yang berbeda atas satisfaction terhadap suatu bisnis atau usaha. Perusahaan harus dapat melakukan aktivitas bisnis atau usaha yang sedapat mungkin memberikan atau mendekati tingkat satisfaction kepada pelanggan yang menggunakan produk atau jasa perusahaan yang bersangkutan karena satisfaction pelanggan merupakan faktor yang penting dalam mempertahankan bisnis atau usaha perusahaan

Satisfaction pelanggan menurut Kotler \& Keller, Kevin (2013) adalah suatu perasaan senang atau kecewa seseorang yang muncul setelah membandingkan antara persepsi atau kesannya terhadap kinerja atau hasil suatu produk dan harapan-harapannya. Menurut Oliver dalam Tjiptono (2005) dengan bukunya "Satisfaction: A Behavioral Perpective on the Customer" menyatakan bahwa semua orang paham apa itu kepuasan, tetapi begitu diminta mendefinisikannya, kelihatannya tak seorangpun tahu. Kesimpulan yang dapat diambil dari definisi di atas adalah bahwa pada dasarnya pengertian satisfaction pelanggan mencakup perbedaan antara harapan dengan hasil dari kinerja yang dirasakan oleh seseorang atau sekelompok orang. Indikator yang digunakan menurut Kotler \& Keller, Kevin (2013) yaitu perasaan senang, kenyataan sesuai dengan harapan dan merasa puas atas keseluruhan pelayanan. Dalam penelitian ini, definisi satisfaction menunjuk pendapat Kotler \& Keller (2013) yaitu suatu perasaan senang atau kecewa seseorang yang muncul setelah membandingkan antara persepsi atau kesannya terhadap hasil suatu produk dan harapan-harapannya.

Trust adalah keyakinan bahwa seseorang akan menemukan apa yang diinginkan pada mitra pertukaran. Trust melibatkan kesediaan seseorang untuk bertingkah laku tertentu karena keyakinan bahwa mitranya akan memberikan apa yang ia harapkan dan suatu harapan yang dimiliki seseorang bahwa janji dapat dipercaya (Barnes, 2003). Menurut Kotler \& Keller (2013), Trust adalah gagasan deskriptif yang dianut oleh seseorang tentang sesuatu. Indikator yang digunakan menurut Meyer (1995) yaitu ability, benevolence dan intergritas. Dalam penelitian ini, definisi Trust menunjuk kepada pendapat Kotler \& Keller (2013) bahwa trust adalah gagasan deskriptif yang dianut oleh seseorang tentang sesuatu.

Customer retention adalah suatu bentuk kecenderungan masa depan pelanggan untuk tetap setia dan loyal terhadap penyedia layanan (Ranaweera \& Prabhu, 2003). Dwyer \& Tanner (1999) menyatakan customer retention memiliki pengaruh yang sangat kuat terhadap profit. Peningkatan customer retention akan mengakibatkan adanya peningkatan pada profit. Karena hubungan baik yang terjalin antara perusahaan dengan pelanggan dan bukan karena adanya keterpaksaan pelanggan karena tidak adanya alternatif provider lain atau besarnya switching cost.

Customer retention adalah sebuah bentuk keterikatan bathin antara pelanggan atau konsumen dengan produsen atau perusahaan yang ditandai dengan pembelian yang berulang dan bersifat jangka panjang (Kotler \& Keller, 2013). Dengan demikian pengertian Customer retention adalah segala bentuk kegiatan dan aktivitas yang 
diarahkan oleh produsen untuk menjaga hubungan yang baik dan berkelanjutan dengan pelanggan atau konsumennya dalam jangka panjang. Indikator yang digunakan menurut Kotler \& Keller (2013) yaitu keandalan, daya tangkap, kepastian, empati dan berwujud. Magatef \& Tomalieh (2015) yaitu repurchase, probability to switch dan rekomendasi pada pihak lain. Dalam penelitian ini, definisi customer retention menunjuk kepada pendapat Kotler \& Keller (2013) yaitu sebuah bentuk keterikatan bathin antara pelanggan atau konsumen dengan produsen atau perusahaan yang ditandai dengan pembelian yang berulang dan pada dasarnya bersifat jangka panjang .

Untuk mendukung penelitian ini, maka penelitian terdahulu yang dijadikan acuan, arahan dan pegangan bagi penulis,antara lain: Penelitian oleh Aryani \& Rosinta (2010) dan oleh Budiarti (2011) yang menganalisis pengaruh service quality dan complain handling terhadap satisfaction, dengan metode structural equation modeling analysis dan hasil membuktikan bahwa secara keseluruhan variabel service quality berpengaruh terhadap satisfaction pelanggan. Penelitian oleh Rizan \& Anjarestu (2013) dan oleh Zuliantin (2016), yang menganalisis pengaruh variable personal selling terhadap satisfaction, dengan metode analisis regresi berganda, hasil membuktikan bahwa personal selling berpengaruh terhadap satisfaction. Penelitian oleh Salay (2013) yang menganalisis pengaruh complain handling terhadap satisfaction, dengan metode regresi berganda, dan hasil membuktikan bahwa complain handling memiliki pengaruh terhadap satisfaction.

Penelitian oleh Rimawan, Mustofa, \& Mulyanto (2017), yang menganalisis pengaruh variable satisfaction dan trust terhadap loyalitas pelanggan, dengan metode regresi berganda, hasil membuktikan bahwa satisfaction memiliki pengaruh terhadap trust. Penelitian oleh Odunlami (2015) yang menganalisis variabel satisfaction terhadap customer retention, dengan metode regresi analisis, hasil membuktikan bahwa terdapat hubungan satisfaction dan customer retention. Penelitian oleh Sarwar, Abbasi, \& Pervaiz (2012) yang meneliti pengaruh variabel trust terhadap loyalitas dan customer retention, dengan metode analisis korelasi dan hasil membuktikan bahwa trust berpengaruh terhadap customer retention. Penelitian oleh Esti, Lubis, \& Wijayanto (2013) yang meneliti pengaruh customer retention melalui satisfaction, dengan metode analisis deskriptif dan hasilnya bahwa satisfaction berpengaruh terhadap customer retention. 


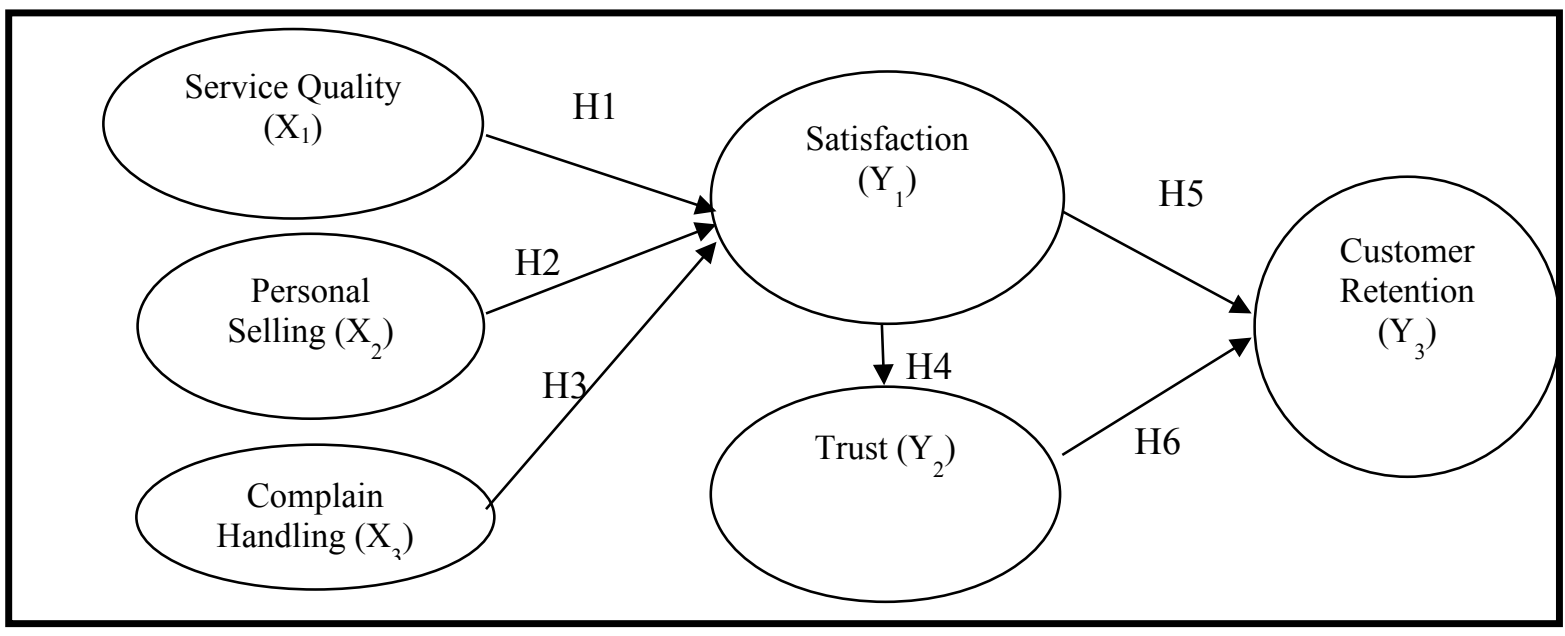

Gambar 1. Model Penelitian

\subsection{Hubungan Variabel Service Quality terhadap Satisfaction}

Hubungan variabel service quality terhadap satisfaction secara teoritis maupun empiris adalah signifikan seperti penelitian (Budiarti, 2011). Secara teoritis ketika service quality yang diberikan mampu memenuhi atau melampaui harapan pelanggan maka pelanggan merasa puas (Parasuraman, Zeithaml, \& Berry, 1988). Secara empiris banyak penelitian dengan latar belakang sampel yang berbeda-beda telah membuktikan bahwa service quality mempunyai pengaruh signifikan terhadap satisfaction seperti Budiarti (2011), serta Aryani \& Rosinta (2010). Hipotesis yang digunakan adalah:

$\mathbf{H}_{1}$ : Service quality berpengaruh terhadap satisfaction nasabah tabungan Bank Harda Internasional Cabang Pontianak

\subsection{Hubungan Variabel Personal Selling terhadap Satisfaction}

Hubungan variabel personal selling terhadap satisfaction adalah signifikan seperti penelitian (Zuliantin, 2016). Secara teoritis ketika personal selling yang diberikan mampu memenuhi atau melampaui pengharapan maka pelanggan akan merasa puas (Parasuraman et al., 1988). Secara empiris banyak penelitian dengan latar belakang sampel yang berbeda-beda telah membuktikan bahwa personal selling mempunyai pengaruh signifikan terhadap satisfaction pelanggan seperti Zuliantin (2016) serta Rizan \& Anjarestu (2013). Hipotesis yang digunakan adalah:

$\mathbf{H}_{2}$ : Personal selling berpengaruh terhadap Satisfaction nasabah tabungan Bank Harda Internasional Cabang Pontianak.

\subsection{Hubungan Variabel Complain Handling terhadap Satisfaction}

Hubungan variabel complain handling terhadap satisfaction adalah signifikan seperti penelitian Budiarti (2011). Secara teoritis ketika complain handling yang diberikan semakin baik, maka pelanggan merasa puas (Parasuraman et al., 1988). Secara 
empiris banyak penelitian dengan latar belakang sampel yang berbeda-beda telah membuktikan bahwa complain handling mempunyai pengaruh signifikan terhadap satisfaction pelanggan seperti Budiarti (2011) dan Salay (2013). Hipotesis yang digunakan adalah:

$\mathbf{H}_{3}$ : Complain handling berpengaruh terhadap satisfaction nasabah tabungan Bank Harda Internasional Cabang Pontianak.

\subsection{Hubungan Variabel Satisfaction terhadap Trust}

Hubungan variabel satisfaction terhadap trust adalah signifikan seperti penelitian Rimawan et al (2017). Secara empiris banyak penelitian dengan latar belakang sampel yang berbeda-beda telah membuktikan bahwa satisfaction mempunyai pengaruh signifikan terhadap trust seperti yang telah diungkapkan oleh Rimawan et al (2017) dan Hennig-Thurau \& Klee (1997). Hipotesis yang digunakan adalah:

$\mathbf{H}_{4}$ : Satisfaction berpengaruh signifikan terhadap trust nasabah tabungan Bank Harda Internasional Cabang Pontianak.

\subsection{Hubungan Variabel Satisfaction terhadap Customer Retention}

Hubungan variabel satisfaction terhadap customer retention adalah signifikan seperti penelitian oleh Odunlami (2015). Secara empiris banyak penelitian dengan latar belakang sampel yang berbeda-beda telah membuktikan bahwa satisfaction mempunyai pengaruh signifikan terhadap customer retention seperti Odunlami (2015), Sarwar et al., (2012), Esti et al., (2013), dan Zulkifli (2012). Hipotesis yang digunakan adalah:

$\mathbf{H}_{5}$ : Satisfaction berpengaruh signifikan terhadap customer retention nasbaah tabungan Bank Harda Internasional Cabang Pontianak.

\subsection{Hubungan Variabel Trust terhadap Customer Retention}

Hubungan variabel trust terhadap customer retention adalah signifikan seperti penelitian (Odunlami, 2015). Secara empiris banyak penelitian dengan latar belakang sampel yang berbeda-beda telah membuktikan bahwa trust mempunyai pengaruh signifikan terhadap customer retention seperti Odunlami (2015), Sarwar et al., (2012), Esti et al., (2013), dan Zulkifli (2012). Hipotesis yang digunakan adalah:

H$_{6}$ : Trust berpengaruh signifikan terhadap Customer Retention nasabah tabungan Bank Harda Internasional Cabang Pontianak.

Dalam penelitian ini akan dilakukan dengan 3 struktur penelitian yaitu :
a) Struktur pertama : $\quad \mathrm{Y}_{1}=\mathrm{Py}_{1 \mathrm{X} 1}+\mathrm{Py}_{1 \mathrm{X} 2}+\mathrm{Py}_{1 \mathrm{X} 3}+\mathrm{e}$
b).struktur kedua : $\quad \mathrm{Y}_{2}=\mathrm{Py}_{2} \mathrm{y}_{1}+\mathrm{e}$
c) Struktur ketiga : $\quad \mathrm{Y}_{3}=\mathrm{Py}_{3} \mathrm{y}_{1}+\mathrm{Py}_{3} \mathrm{y}_{2}+\mathrm{e}$ 
dimana:

$\mathrm{Y}_{1} \quad=$ Satisfaction

$\mathrm{Y}_{2} \quad=$ Trust

$\mathrm{Y}_{3} \quad=$ Customer Retention

$\mathrm{X}_{1} \quad$ Service Quality

$\mathrm{X}_{2} \quad=$ Personal Selling

$\mathrm{X}_{3} \quad=$ Complain Handling

$\mathrm{Py}_{1}, \mathrm{Py}_{2}, \mathrm{Py}_{3}=$ Koefisien regresi

e $\quad=$ Standard error

\section{METODA PENELITIAN}

Penelitian ini menggunakan jenis penelitian survei dan penelitian asosiatif berupa penelitian kausal dengan metode path analysis. Variabel dependen adalah customer retention $\left(\mathrm{Y}_{3}\right)$ yaitu kesediaan untuk tetap menjadi nasabah Bank Harda Cabang Pontianak seperti keinginan untuk melakukan transaksi kembali, tidak terpengaruh dengan perusahaan lain, merekomendasikan perusahaan. Variabel independen adalah service quality, personal selling, dan complain handling yang terdiri dari: service quality $\left(\mathrm{X}_{1}\right)$ yaitu keseluruhan ciri serta sifat dari produk/ pelayanan Bank Harda yang berpengaruh pada kemampuan marketing Bank Harda untuk memenuhi kebutuhan nasabah seperti keandalan, daya tanggap, kepastian, empati, dan berwujud. Personal selling yaitu sebuah pengungkapan secara lisan oleh marketing Bank Harda dalam menghadapi seseorang atau beberapa nasabah untuk menciptakan suatu penjualan seperti komunikasi, sikap, penguasaan produk, negosiator, dan responsive. Complain handling yaitu kemampuan Bank Harda untuk dapat mencegah, menyelesaikan suatu konfiks secara nyata dan mendiskusikan secara terbuka dengan nasabah seperti: keadilan, kewajaran, dan accessible.

Variabel mediasi adalah satisfaction $\left(\mathrm{Y}_{1}\right)$ serta trust $\left(\mathrm{Y}_{2}\right)$. Satisfaction yaitu perasaan senang atau kecewa nasabah Bank Harda dengan cara membandingkan antara persepsi dengan kinerja suatu layanan atau produk Bank Harda seperti perasaan senang, kenyataan sesuai dengan harapan, dan merasa puas atas keseluruhan pelayanan. Trust yaitu gagasan deskriptif yang dianut/diyakini oleh nasabah terhadap Bank Harda seperti ability, benevolence dan intergritas. Populasi dalam penelitian ini dibatasi hanya pada nasabah Tabungan PT. Bank Harda Internasional Cabang Pontianak pada tahun 2012 2016 sebanyak 347 nasabah, sedangkan sampel sebanyak 100 nasabah. Data primer diperoleh dari penyebaran kuesioner yang dilakukan penulis kepada responden, sedangkan data sekunder dikumpulkan dengan mempelajari teori-teori dari berbagai sumber eksternal seperti literatur jurnal, artikel-artikel terkait dari majalah, koran dan website. Analisis data yang digunakan untuk menguji hipotesis dengan path analysis yang tujuan untuk menganalisis data guna mengetahui pengaruh antar variabel. 


\section{HASIL PENELITIAN DAN PEMBAHASAN}

\subsection{Uji Validitas dan Uji Reliabilitas}

Berdasarkan pengujian dengan program SPSS ver.17, maka hasil uji validitas memperlihatkan nilai $r_{\text {hitung }}$ semua indikator variabel $>$ dibanding nilai $r_{\text {tabel }}$. dinyatakan valid. Nilai Alpha Cronbach semua variabel $>$ dari 0,60 sehingga dapat disimpulkan bahwa indikator yang digunakan dinyatakan handal.

\subsection{Uji Asumsi Klasik}

Berdasarkan uji asumsi klasik yang digunakan yaitu uji normalitas, uji linieritas, uji multikolinieritas dan uji heterokedastisitas maka diketahui semua variabel berdistribusi normal, mempunyai hubungan yang linier, tidak menunjukkan adanya gejala multikolinieritas, dan tidak terdapat masalah heterokedastisitas.

\subsection{Analisis Struktur Pertama}

Nilai $R$ Square 0,307 (30,7\%), berarti kemampuan variabel service quality $\left(\mathrm{X}_{1}\right)$, personal selling $\left(\mathrm{X}_{2}\right)$, complain handling $\left(\mathrm{X}_{3}\right)$ untuk menjelaskan variabel satisfaction $\left(\mathrm{Y}_{1}\right)$ sebesar 30,7\%, sedangkan 69,3\% dipengaruhi oleh faktor lain yang tidak dipelajari dalam penelitian ini.

Tabel 1. Model Summary

\begin{tabular}{|c|c|c|c|c|}
\hline Model & $\mathrm{R}$ & $\mathrm{R}$ Square & Adjusted R Square & Std. Error of the Estimate \\
\hline 1 & $.554^{\mathrm{a}}$ & .307 & .285 & 1.37686 \\
\hline
\end{tabular}

Predictors: (Constant), $\mathrm{X}_{1}, \mathrm{X}_{2}, \mathrm{X}_{3}$ Dependen variabel : Satisfaction $\mathrm{Y}_{1}$

\subsection{Uji t (Uji Parsial)}

Berdasarkan hasil penelitian menunjukkan bahwa nilai signifikan dari variabel bebas $<$ dari 0,05 , maka dinyatakan bahwa variabel bebas memiliki pengaruh dengan variabel terikat. Persamaan struktur pertama:

$$
\mathrm{Y}_{1}=0,212 \mathrm{X}_{1}+0,282 \mathrm{X}_{2}+0,305 \mathrm{X}_{3}
$$

Berdasarkan hasil penelitian menunjukkan bahwa nilai signifikan variabel Service Quality, Personal Selling dan Complain Handling $<$ dari nilai probabilitas sebesar 0,05 maka $\mathrm{H}_{0}$ ditolak dan $\mathrm{H}_{1}$ diterima, sehingga variabel Service Quality, Personal Sellling dan Complain Handling memiliki pengaruh terhadap variabel Satisfaction. 


\subsection{Analisis Struktur Kedua}

Tabel 2. Model Summary

\begin{tabular}{|c|c|c|c|c|}
\hline Model & $\mathrm{R}$ & R Square & Adjusted R Square & Std. Error of the Estimate \\
\hline 1 & $.213^{\mathrm{a}}$ & .046 & .036 & 1.58222 \\
\hline
\end{tabular}

Predictors: (Constant), $\mathrm{Y}_{1}$

Dependen variabel $: \mathrm{Y}_{2}$

Nilai $R$ Square $0,046(4,6 \%)$, yang berarti bahwa kemampuan variabel Satisfaction $\left(\mathrm{Y}_{1}\right)$ terhadap variabel Trust $\left(\mathrm{Y}_{2}\right)$ sebesar $4,6 \%$, sedangkan $95,4 \%$ dipengaruhi faktor lain yang tidak dipelajari dalam penelitian ini.

\subsection{Uji t (Uji Parsial)}

Berdasarkan hasil penelitian menunjukkan bahwa nilai signifikan dari Satisfaction sebesar 0,033 yang berarti < dari 0,05, maka dinyatakan bahwa Satisfaction memiliki pengaruh dengan Trust. Persamaan struktur kedua:

$$
\mathrm{Y}_{2}=0,213 \mathrm{Y}_{1}
$$

Berdasarkan hasil penelitian juga menunjukkan bahwa nilai signifikan variabel Satisfaction sebesar 0,033, yang berarti bahwa nilai probabilitas signifikan $<$ dari nilai probabilitas yaitu 0,05 maka $\mathrm{H}_{0}$ ditolak dan $\mathrm{H}_{1}$ diterima, sehingga variabel Satisfaction berpengaruh terhadap variabel trust.

\subsection{Analisis Struktur Ketiga}

Tabel 3. Model Summary

\begin{tabular}{|c|c|c|c|c|}
\hline Model & $\mathrm{R}$ & $\mathrm{R}$ Square & Adjusted R Square & Std. Error of the Estimate \\
\hline 1 & $.350^{\mathrm{a}}$ & .122 & .104 & 1.70214 \\
\hline
\end{tabular}

Predictors: (Constant), $\mathrm{Y}_{1}, \mathrm{Y}_{2}$ Dependen variabel : $\mathrm{Y}_{2} 3$

Nilai $R$ Square sebesar 0,122 (12,2\%), yang berarti bahwa kemampuan variabel satisfaction $\left(\mathrm{Y}_{1}\right)$ dan variabel Trust $\left(\mathrm{Y}_{2}\right)$ terhadap customer retention $\left(\mathrm{Y}_{3}\right)$ sebesar $12,2 \%$, sedangkan sebesar $87,8 \%$ dipengaruhi oleh faktor lain yang tidak dipelajari dalam penelitian ini.

\subsection{Uji t (Uji Parsial)}

Berdasarkan hasil penelitian menunjukkan bahwa nilai signifikan dari variabel satisfaction sebesar 0,026 dan nilai signifikan dari trust sebesar 0,021 yang berarti nilai signifikan variabel satisfaction dan trust lebih $<0,05$, maka dinyatakan bahwa variabel satisfaction dan trust memiliki pengaruh terhadap variabel customer retentiont. Persamaan struktur ketiga: 


$$
\mathrm{Y}_{3}=0,221 \mathrm{Y}_{1}+0,228 \mathrm{Y}_{2}
$$

Berdasarkan hasil penelitian menunjukkan bahwa nilai signifikan variabel satisfaction sebesar 0,033 , yang berarti bahwa nilai probabilitas signifikan $<$ dari nilai probabilitas yaitu 0,05 maka $\mathrm{H}_{0}$ ditolak dan $\mathrm{H}_{5}$ diterima, sehingga variabel satisfaction berpengaruh terhadap variabel customer retention.

Berdasarkan Gambar 2 dapat dijelaskan bahwa variabel bebas yang berpengaruh lebih besar terhadap Satisfaction adalah complain handling (0,305), sedangkan satisfaction dan trust yang berpengaruh lebih besar terhadap customer retention adalah Satisfaction $(0,221)$, trust hanya sebesar $(0,213 * 0,228=0,049)$.

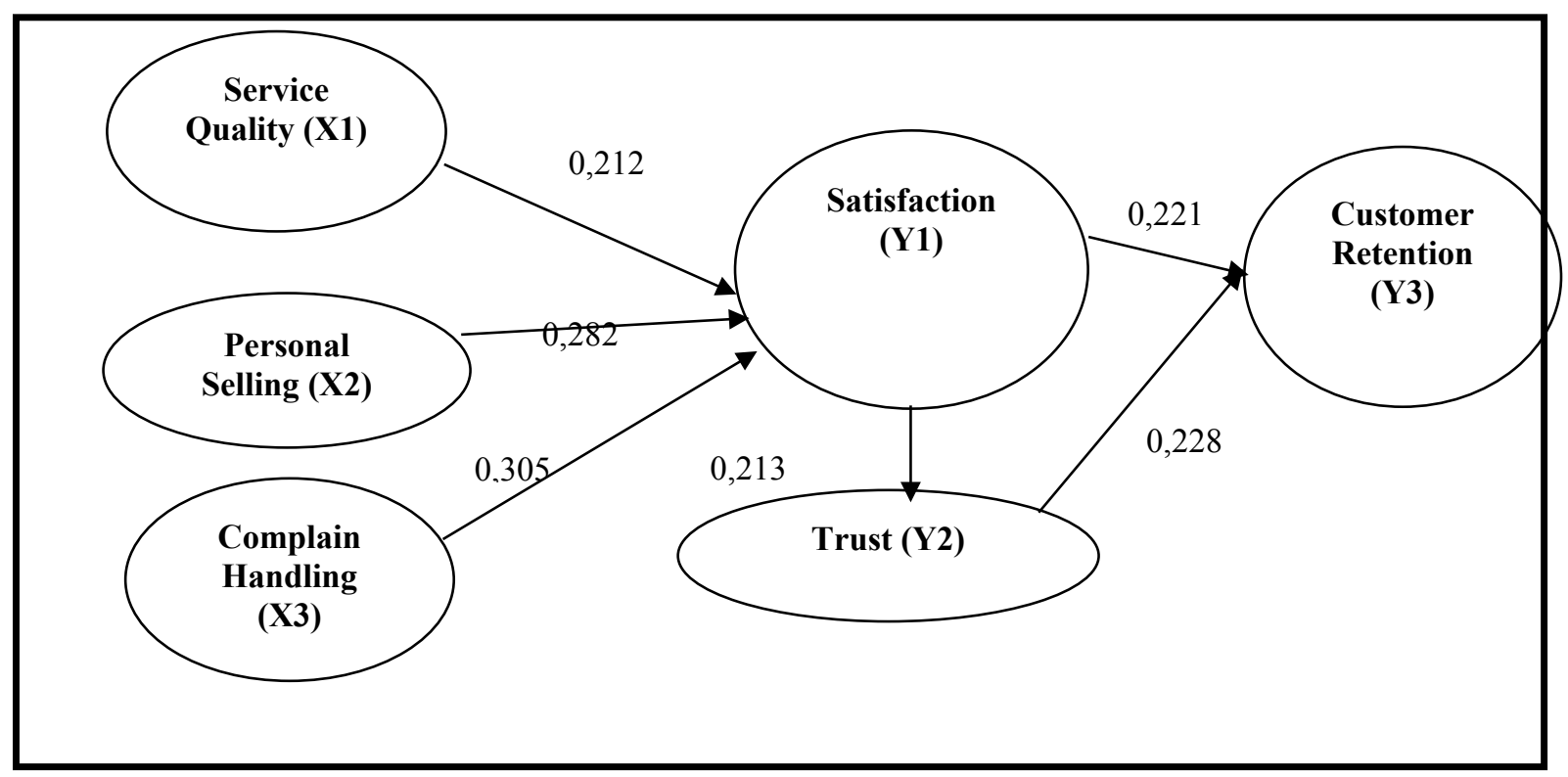

Gambar 2. Diagram Path Dengan Nilai Koefisien Jalur Masing-Masing Variabel

\subsection{Service Quality $\left(\mathrm{X}_{1}\right)$ Berpengaruh terhadap Satisfaction $\left(\mathrm{Y}_{1}\right)$}

Hasil analisis menunjukkan service quality $\left(\mathrm{X}_{1}\right)$ mempengaruhi responden untuk satisfaction $\left(\mathrm{Y}_{1}\right)$ terhadap Bank Harda Internasional Cabang Pontianak, yang berarti semakin responden merasa service quality $\left(\mathrm{X}_{1}\right)$ meningkat maka akan berdampak pada meningkatnya satisfaction $\left(\mathrm{Y}_{1}\right)$. Responden menyatakan bahwa Bank Harda Internasional Cabang Pontianak sudah memiliki kenyamanan fisik bangunan, memiliki halaman parkir yang memadai, merupakan bank yang dapat diandalkan, staffnya tanggap dalam melayani nasabahnya, staffnya terampil dalam melaksanakan pekerjaannya serta staffnya peduli terhadap kebutuhan nasabahnya. Tanggapan tentang Service Quality Bank Harda Internasional Cabang Pontianak mampu mendorong responden merasa satisfaction yang tercermin dari responden yang merasa senang atas jasa yang diberikan, layanan perbankan selama ini sudah memenuhi harapan responden serta responden merasa puas atas keseluruhan jasa perbankan. Hasil penelitian ini mendukung penelitian 
yang dilakukan oleh Budiarti (2011), serta Aryani \& Rosinta (2010), yang mengatakan service quality berpengaruh terhadap satisfaction.

\subsection{Personal Selling $\left(\mathrm{X}_{2}\right)$ Berpengaruh terhadap Satisfaction $\left(\mathrm{Y}_{1}\right)$}

Hasil analisis menunjukkan bahwa personal selling $\left(\mathrm{X}_{2}\right)$ mempengaruhi responden untuk satisfaction $\left(\mathrm{Y}_{1}\right)$ terhadap Bank Harda Internasional Cabang Pontianak, yang berarti bahwa semakin responden merasa personal selling $\left(\mathrm{X}_{2}\right)$ meningkat maka akan berdampak pada meningkatnya satisfaction $\left(\mathrm{Y}_{1}\right)$. Responden menyatakan bahwa staff Bank Harda Internasional Cabang Pontianak sudah memiliki penguasaan produk perbankan yang baik, memiliki kemampuan negosiator yang baik serta memiliki kemampuan responsif pada nasabah yang baik. Tanggapan tentang personal selling Bank Harda Internasional Cabang Pontianak yang demikian mampu mendorong responden untuk merasa satisfaction yang tercermin dari responden yang merasa senang atas jasa yang diberikan, layanan selama ini sudah memenuhi harapan responden serta responden merasa puas atas keseluruhan jasa perbankan. Hasil penelitian ini mendukung penelitian yang dilakukan oleh Zuliantin (2016). serta Rizan \& Anjarestu (2013), yang menyatakan bahwa personal selling $\left(\mathrm{X}_{2}\right)$ berpengaruh terhadap satisfaction $\left(\mathrm{Y}_{1}\right)$.

\subsection{Complain Handling $\left(\mathrm{X}_{3}\right)$ Berpengaruh terhadap Satisfaction $\left(\mathrm{Y}_{1}\right)$}

Hasil analisis menunjukkan bahwa complain handling $\left(\mathrm{X}_{3}\right)$ mempengaruhi responden untuk satisfaction $\left(\mathrm{Y}_{1}\right)$ terhadap Bank Harda Internasional Cabang Pontianak, yang berarti bahwa semakin responden merasa complain handling $\left(\mathrm{X}_{3}\right)$ semakin ditangani dengan baik, maka akan berdampak pada meningkatnya Satisfaction $\left(\mathrm{Y}_{1}\right)$. Responden menyatakan Bank Harda Internasional Cabang Pontianak dapat memberikan rasa adil atas komplain, proses penyampaian komplain sudah ditangani sewajarnya serta responden tidak mengalami kesulitan untuk menyampaikan komplain. Tanggapan tentang complain handling Bank Harda Internasional Cabang Pontianak yang demikian mampu mendorong responden untuk merasa Satisfaction yang tercermin dari responden yang merasa senang atas jasa yang diberikan, layanan selama ini sudah memenuhi harapan responden serta responden merasa puas atas keseluruhan jasa perbankan. Hasil penelitian ini mendukung hasil penelitian sebelumnya yang dilakukan oleh Budiarti (2011) dan Salay (2013). yang menyatakan bahwa complain handling berpengaruh terhadap Satisfaction $\left(\mathrm{Y}_{1}\right)$.

\subsection{Satisfaction $\left(\mathrm{Y}_{1}\right)$ berpengaruh terhadap Trust $\left(\mathrm{Y}_{2}\right)$}

Dari hasil analisis menunjukkan bahwa satisfaction $\left(\mathrm{Y}_{1}\right)$ mempengaruhi responden untuk trust $\left(\mathrm{Y}_{2}\right)$ terhadap Bank Harda Internasional Cabang Pontianak, yang berarti bahwa semakin responden merasa satisfaction $\left(\mathrm{Y}_{1}\right)$ meningkat dari Bank Harda Internasional Cabang Pontianak berdampak pada meningkatnya trust $\left(\mathrm{Y}_{2}\right)$. Responden menyatakan senang atas jasa yang diberikan oleh Bank Harda Internasional Cabang 
Pontianak, layanan selama ini sudah memenuhi harapan responden serta responden merasa puas atas keseluruhan jasa perbankan yang diberikan oleh Bank Harda Internasional Cabang Pontianak. Tanggapan tentang Satisfaction yang demikian mampu mendorong responden untuk merasa trust yang tercermin dari responden merasa percaya bahwa staff Bank Harda Internasional Cabang Pontianak memiliki kompetensi atau kemampuan yang baik, memiliki kemampuan bekerja maksimal serta memiliki kekompakan dan intergritas yang tinggi. Hasil penelitian ini mendukung penelitian yang dilakukan oleh oleh Rimawan et al., (2017) dan Hennig-Thurau \& Klee (1997), yang menyatakan bahwa satisfaction berpengaruh terhadap trust.

\subsection{Satisfaction $\left(\mathrm{Y}_{1}\right)$ dan Trust $\left(\mathrm{Y}_{2}\right)$ berpengaruh terhadap Customer Retention $\left(\mathrm{Y}_{3}\right)$}

Dari hasil analisis menunjukkan bahwa satisfaction $\left(\mathrm{Y}_{1}\right)$ dan trust $\left(\mathrm{Y}_{2}\right)$ mempengaruhi responden untuk customer retention $\left(\mathrm{Y}_{3}\right)$ terhadap Bank Harda Internasional Cabang Pontianak, yang berarti bahwa semakin responden merasa satisfaction $\left(\mathrm{Y}_{1}\right)$ dan trust $\left(\mathrm{Y}_{2}\right)$ meningkat maka akan menyebabkan meningkatnya customer retention $\left(\mathrm{Y}_{3}\right)$. Responden menyatakan senang atas jasa yang diberikan oleh Bank Harda Internasional Cabang Pontianak, layanan Bank Harda Internasional Cabang Pontianak yang selama ini sudah memenuhi harapan responden serta responden merasa puas atas keseluruhan jasa perbankan yang diberikan oleh Bank Harda Internasional Cabang Pontianak.

Responden juga menyatakan bahwa staff Bank Harda Internasional Cabang Pontianak memiliki kompetensi atau kemampuan yang baik, memiliki kemampuan bekerja maksimal untuk memberikan kepuasan kepada nasabah serta memiliki kekompakan dan intergritas yang tinggi. Tanggapan tentang satisfaction dan trust yang demikian mendorong responden untuk merasa customer retention yang tercermin dari responden yang tetap berkeinginan melakukan transaksi perbankan, responden tidak mudah terpengaruh dengan penawaran produk atau layanan perbankan dari bank lain serta merekomendasikan Bank Harda Internasional Cabang Pontianak kepada orang lain. Hasil penelitian ini mendukung penelitian yang dilakukan oleh Odunlami (2015), Sarwar et al., (2012), Esti et al., (2013), dan Zulkifli (2012), yang menyatakan bahwa satisfaction dan trust berpengaruh terhadap customer retention responden.

\section{SIMPULAN}

Berdasarkan hasil penelitian dan pembahasan maka dapat disimpulkan bahwa variabel service quality, personal selling dan complain handling berpengaruh terhadap variabel satisfaction, variabel satisfaction berpengaruh terhadap variabel trust, variabel satisfaction dan variabel trust berpengaruh terhadap variabel customer retention serta hasil penelitian menunjukkan semua variabel dalam penelitian ini mempunyai pengaruh antar variabel dan pengujian hipotesis menunjukkan hasil yang signifikan. 
Berdasarkan hasil penelitian maka dapat diberikan rekomendasi yaitu bahwa variabel service quality, personal selling, complain handling, berpengaruh terhadap variabel satisfaction dan variabel trust yang pada akhirnya akan berpengaruh terhadap variabel customer retention, maka perlu mempertahankan dan meningkatkan variabel service quality, personal selling, complain handling pada usaha perbankan. Secara keseluruhan, Bank Harda Internasional Cabang Pontianak perlu secara rutin memperhatikan variabel service quality, personal selling, complain handling agar tetap terjaga dan semakin meningkat dari waktu ke waktu. Temuan ini diharapkan dapat memberikan informasi bagi pihak Bank Harda Internasional Cabang Pontianak untuk meningkatkan variabel service quality, personal selling, complain handling kepada nasabahnya.

\section{DAFTAR PUSTAKA}

Artantie, N. (2014). Pengaruh Komunikasi, Kepercayaan, Komitmen dan Penyelesaian Masalah Terhadap Loyalitas Nasabah (Studi Pada Nasabah Debitur PD. BPR Tugu Artha Malang). Jurnal Ilmiah Mahasiswa FEB Universitas Brawijaya, 2(1).

Aryani, D., \& Rosinta, F. (2010). Pengaruh Kualitas Layanan terhadap Kepuasan Pelanggan dalam Membentuk Loyalitas Pelanggan. Jurnal Ilmu Administrasi Dan Organisasi, 17(2), 114-126.

Barnes, J. G. (2003). Establishing Meaningful Customer Relationships: Why Some Companies and Brands Mean More To Their Customers. Managing Service Quality: An International Journal, 13(3), 178-186. https://doi.org/https://doi.org/10.1108/09604520310476445.

Budiarti, A. (2011). Pengaruh Kualitas Layanan dan Penanganan Keluhan Terhadap Kepuasan dan Loyalitas Nasabah Bank Umum Syariah di Surabaya. EKUITAS (Jurnal Ekonomi Dan Keuangan), 15(2), 210-231.

Dharmmesta, B. S., \& Irawan. (2002). Manajemen Pemasaran Modern. Yogyakarta: Liberty.

Doyle, C. (2013). Kamus Pemasaran. Jakarta: Indeks.

Dwyer, F. R., \& Tanner, J. F. (1999). Business Marketing: Connecting Strategy, Relationships, and Learning. New York: McGraw-Hill.

Ellena, F., \& Rahardjo, S. T. (2011). Analisis Pengaruh Kepercayaan, Komitmen, Komunikasi, dan Penanganan Keluhan Terhadap Loyalitas Nasabah (Studi Pada Nasabah PT. BRI (Persero) Tbk. Cabang Pemalang). Skripsi Fakultas Ekonomi Universitas Diponegoro.

Esti, W., Lubis, N., \& Wijayanto, A. (2013). Pengaruh Nilai Pelanggan Terhadap Retensi Pelanggan Melalui Kepuasan (Studi Pada Mahasiswa Jurusan Administrasi Bisnis Universitas Diponegoro Angkatan 2009 - 2012 Pengguna Layanan Data Smartfren). Diponegoro Journal of Social and Politic, 1-10.

Hasan, A. (2013). Marketing dan Kasus - Kasus Pilihan. CAPS (Center for Academic Publishing Service). 
Hennig-Thurau, T., \& Klee, A. (1997). The Impact of Customer Satisfaction and Relationship Quality on Customer Retention: A Critical Reassessment and Model Development". Psychology \&Marketing, 14(8), 737-764.

Kasmir. (2014). Manajemen Perbankan. Jakarta: PT RajaGrafindo Persada.

Kotler, P., \& Keller, K. L. (2012). Manajemen Pemasaran. Jakarta: Erlangga.

Kotler, P., \& Keller, K. L. (2013). Manajemen Pemasaran. Jakarta: Erlangga.

Kwon, I.-W. G., \& Suh, T. (2006). Factors Affecting The Level of Trust and Commitment in Supply Chain Ralationships. Journal of Supply Chain Management, 40(1), 4-14.

Lovelock, Christopher, H., \& Wright, Lauren, K. (2007). Manajemen Pemasaran Jasa. Jakarta: Indeks.

Magatef, S. G., \& Tomalieh, E. F. (2015). The Impact of Customer Loyalty Programs on Customer Retention. International Journal of Business and Social Science, 6(8), 78-93. https://doi.org/10.1080/15332969.2015.1046776.

Mauludin, H. (2004). Essay: Analisis Kualitas Pelayanan, Pengaruhnya terhadap Citra (Image) Rumah Sakit.

Meyer, B. D. (1995). Natural and Quasi-Experiments in Economics. Journal of Business and Economic Statistics, 13(2), 151-161.

Ndubisi, N. O. (2005). Factorial and Discriminant Analyses of The Underpinnings of Relationship Marketing and Customer Satisfaction. International Journal of Bank Marketing, 23(7),

542-557. https://doi.org/https://doi.org/10.1108/02652320510629908.

Ndubisi, N. O. (2007). Relationship Marketing and Customer Loyalty. Marketing Intelligence \& Planning, 25(1), 98-106. https://doi.org/https://doi.org/10.1108/02634500710722425.

Ndubisi, N. O. (2012). Relationship Quality: Upshot of Mindfulness-based Marketing Strategy in Small Organisations. International Journal of Quality \& Reliability Management, 29(6), 626-641. https://doi.org/https://doi.org/10.1108/02656711211245638.

Ngatno. (2006). Analisis Pengaruh Umpan Balik Supervisi Terhadap Kinerja Salesman. Jurnal Ilmu Sosial, 5(2), 55-66. https://doi.org/10.1109/TDEI.2009.5211872.

Ningtyas, F., \& Rachmad, B. (2011). Pengaruh Kepercayaan, Komitmen, Komunikasi, Penanganan Masalah Dan Kepuasan Nasabah Terhadap Loyalitas Nasabah Bank Muamalat Di Surabaya. Journal of Business and Banking, 1(1), 51-60.

Odunlami, B. (2015). Impact of Customer Satisfaction on Customer Retention: A Case Study of a Reputable Bank in Oyo, Oyo State. Nigeria. International Journal of Managerial Studies and Research, 3(2), 42-53. Retrieved from www.arcjournals.org.

Parasuraman, A., Zeithaml, V. ., \& Berry, L. . (1988). "SERVQUAL : A Multiple Item Scale for Measuring Customer Perceptions of Service Quality." Journal of Retailing, 64(1), 14-40. 
Ranaweera, C., \& Prabhu, J. (2003). The Influence of Satisfaction, Trust and Switching Barriers on Customer Retention in a Continuous Purchasing Setting. International Journal of Service Industry Management, 14(4), 374-395. https://doi.org/https://doi.org/10.1108/09564230310489231.

Rimawan, E., Mustofa, A., \& Mulyanto, A. D. (2017). The Influence of Product Quality, Service Quality and Trust on Customer Satisfaction and Its Impact on Customer Loyalty (Case Study PT ABC Tbk). International Journal of Scientific \& Engineering Research, 8(7), 2330-2336.

Rizan, M., \& Anjarestu, Y. (2013). Pengaruh Kualitas Produk Dan Personal Selling Terhadap Kepuasan Pelanggan Pada Majalah Info Bekasi ( Studi Kasus PT.SIBK ). Jurnal Riset Manajemen Sains Indonesia, 4(1), 74-96.

Rooswitasari, T. (2013). Prinsip dan Dinamika Pemasaran (Edisi Pert). Yogyakarta: J \& $\mathrm{J}$ Learning.

Salay, V. (2013). Pengaruh Kualitas Layanan Dan Penanganan Komplain Terhadap Kepuasan Nasabah Pada Loyalitas Nasabah Pada Bank BRI Cabang Kertajaya di Surabaya. Kajian Ilmiah Mahasiswa Manajemen. Retrieved from http://journal.wima.ac.id/index.php/KAMMA/article/view/453/425.

Sarwar, M. Z., Abbasi, K. S., \& Pervaiz, S. (2012). The Effect of Customer Trust on Customer Loyalty and Customer Retention: A Moderating Role of Cause Related Marketing. Global Journal of Management And Business Research, 12(6), 26-36.

Schmitt, B. H. (2002). Experiential marketing: How to get customers to sense, feel, think, act and relate to your company and brands. New York: Free Press.

Semuel, H. (2012). Customer Relationship Marketing Pengaruhnya Terhadap Kepercayaan dan Loyalitas Perbankan Nasional. Jurnal Manajemen Pemasaran, 7(1), 33-41. https://doi.org/10.9744/pemasaran.7.5.33-41.

Tjiptono, F. (2005). Manajemen Jasa. Yogyakarta: Penerbit Andi.

Tjiptono, F. (2008). Strategi Menciptakan Kepuasan Pelanggan. dalam Managing Quality Customer Service. Pelayanan yang Berkualitas. Universitas Sanata Dharma.

Wardhana, A., \& Iba, Z. (2014). Pengaruh Penjualan Personal Terhadap Pengetahuan Produk dan Implikasinya Terhadap Keputusan Pembelian Mobil Suv Premium Di Jawa Barat. Jurnal Kebangsaan, 3(5), 1-10.

Zuliantin. (2016). Pengaruh Personal Selling, Direct Selling dan Hubungan Masyarakat Terhadap Kepuasan Nasabah Studi Kasus pada BMT UGT Sidogiri KCP Kanigoro Blitar. An-Nisbah, 3(1), 88-104. https://doi.org/10.21274/an.2016.3.1.87-104.

Zulkifli. (2012). Relationship Marketing terhadap Customer Retention dan Customer Loyalty pada nasabah Bank MEGA, Tbk. Malang. Jurnal Manajemen Dan Akuntansi, 1(1), 1-16. 